\title{
An Australian multituberculate and its palaeobiogeographic implications
}

Thomas H. Rich, Patricia Vickers-Rich, Timothy F. Flannery, Benjamin P. Kear, David J. Cantrill, Patricia Komarower, Lesley Kool, David Pickering, Peter Trusler, Steven Morton, Nicholas van Klaveren, and Erich M.G. Fitzgerald

Acta Palaeontologica Polonica 54 (1), 2009: 1-6 doi:http://dx.doi.org/10.4202/app.2009.0101

A dentary fragment containing a tiny left plagiaulacoid fourth lower premolar from the

Early Cretaceous (Aptian) of Victoria provides the first evidence of the Multituberculata

from Australia. This unique specimen represents a new genus and species, Corriebaatar marywaltersae, and is placed in a new family, Corriebaataridae. The Australian fossil, together with meagre records of multituberculates from South America, Africa, and Madagascar, reinforces the view that Multituberculata had a cosmopolitan distribution during the Mesozoic, with dispersal into eastern Gondwana probably occurring prior to enforcement of climatic barriers (indicated by marked differentiation in regional floras) in the Early Cretaceous.

Key words: Mammalia, Multituberculata, Cimolodonta, Cretaceous, Gondwana, Australia.

Thomas H. Rich [trich@museum.vic.gov.au], David Pickering [dpick@museum.vic.gov.au], Peter Trusler [ptart@ optusnet.com.au], Nicholas van Klaveren [Nicholas.VanKlaveren@goldfields.com.au ], and Erich M.G. Fitzgerald [efitzgerald@museum.vic.gov.au], Museum Victoria, PO Box 666, Melbourne, Victoria 3001, Australia; Patricia Vickers-Rich [pat.rich@sci.monash.edu.au], Patricia

Komarower [Patricia.Komarower@sci.monash.edu.au], and Lesley Kool [koolasuchas@bigpond.com ], School of Geosciences, Monash University, Victoria 3800, Australia; Steven Morton [Steven.Morton@sci.monash.edu.au], School of Physics, Monash University, Victoria 3800, Australia; Timothy F. Flannery [tim.flannery@ textpublishing.com.au], Macquarie University, New South Wales 2109, Australia; Benjamin P. Kear [b.kear@latrobe.edu.au ], Department of Genetics, La Trobe University, Victoria 3086, Australia; David J. Cantrill [david.cantrill@rbg.vic.gov.au], Royal BotanicGardens Melbourne, South Yarra, Victoria 3141, Australia. 
Attribution License (for details please see creativecommons.org), which permits unrestricted use, distribution, and reproduction in any medium, provided the original author and source are credited.

FoF Full text $(230.1 \mathrm{kB})$ 